ISSN (print) 0867-2008 / ISSN (online) 2391-75 I2

DOI: http://dx.doi.org/10.12775/OM.2019.010

DARIUS VON GÜTTNER-SPORZYŃSKI*

School of Historical and Philosophical Studies

Faculty of Arts

The University of Melbourne

Victoria 3010

Australia

email: d.guttner@unimelb.edu.au

\title{
THE LIFE AND CAREER OF A KNIGHT OF MALTA IN THE AGE OF SECULARISATION: MICHELE ENRICO SAGRAMOSO (1720-1791). THE ORDER OF MALTA AND THE FIRST PARTITION OF POLAND
}

\section{KEYWORDS}

history; military orders; Hospitallers; Order of Malta; Poland; Partitions of Poland; Enlightenment; Sagramoso

\begin{abstract}
For contemporary and arguably disinterested British observers, the First Partition of Poland by Russia, Prussia and Austria in 1772 was an "immoral act of appropriation". This "most flagrant violation of natural justice and international law" was perpetrated by three absolute monarchs whose coordinated actions simultaneously removed the political threat of a progressive neighbour and delivered significant territorial gains, whilst cynically claiming to restore the balance of power in Europe. The 1772 Partition of Poland took place at the height of the Enlightenment, a movement which challenged the ancien régime and its mutually reinforcing pillars of the Church and State. This article examines the career of Michele Enrico Sagramoso, a key actor in the manoeuvres that normalised the 1772 Partition. Sagromoso was both the epitome of an enlightened, progressive European and a committed and successful diplomat in the service of the Church's Order of Malta. An examination of Sagramoso's intertwined personal and diplomatic connections helps to explain the success of his mission to Poland and how his efforts facilitated the part-recovery of a contested bequest for the Order, timed and prosecuted at the peak of the Partition crisis. This article contends that Sagramoso significantly contributed to the destabilisation of the already fractured Polish-Lithuanian Parliament, and his actions were both actively supported by and
\end{abstract}

* ORCID: https://orcid.org/0000-0002-1 342-81 67 
benefited the 1772 Partition agenda of Russia, Prussia and Austria. The 1772 Partition and the Polish question became "the most complex diplomatic affair of the entire eighteenth century."

Il the ancien régimes of Europe, including the religious military Order
of Malta, faced a relentless intellectual onslaught in the hundred years
before the French Revolution, a period we know as the Enlightenment. The attacks came from a movement which challenged the established forms of society, politics and religion. Promoters of the "enlightened ideas" insisted that the world should be understood using reason and logic rather than religion and tradition. As the eighteenth century progressed, these ideas became linked to a series of interrelated economic, social and cultural changes and began to undermine the institutional foundations of the European political and social order, which until then had been based on corporate privilege and monarchical authority, and drew on organised religion as one of its foundations. During this period, scientific observation, religious tolerance, rational thought, criticism and human progress became respected and influential ideas. These novel and subversive beliefs were propagated by educated intellectuals who communicated their views in clever, witty and often satirical and daring writings transmitting their ideas in a direct and captivating format far and wide across Europe and the New World within the emerging Republic of Letters.

Also important for the development and propagation of the Enlightenment was the Grand Tour, a requisite experience of the period for those of sufficient means. This international voyage was undertaken as a rite of passage by the educated, cultured individuals who comprised the upper-class milieu. On tour it was "de rigueur" for travellers to observe and report on what they saw of the human condition in the foreign lands in which they travelled, filling journals and writing letters and pamphlets to report to friends and family as well as society at large.

This article will focus on the life of one such learned and enlightened individual who paradoxically (but not atypically) was also a well-connected aristocrat and respected Knight of Malta, Michele Enrico Sagramoso. ${ }^{2}$ Sagramoso was an

I Alain Blondy, "L’ordre de Malte et Malte dans les affaires polonaises et russes au XVIII siècle." Revue des études slaves 66, no. 4 (1994): 733.

2 For the history of the Order of Malta see, for example, Anthony Luttrell, "From Jerusalem to Malta: The Hospital's Character and Evolution," in Peregrinationes: Acta et Documenta, vol. I, ed. Accademia Internazionale Melitense. Conference (Malta: Accademia Internazionale Melitense, 2000), I 3-22; Victor Mallia-Milanes, "A Pilgrimage of Faith, War, and Charity: The Order of the Hospital from Jerusalem to Malta," in Religion, ritual and mythology: aspects of identity formation in Europe, ed. Joaquim Carvalho (Pisa: Pisa University Press, 2006), 83-96; Helen Nicholson, The Knights Hospitaller (Woodbridge: Boydell Press, 200 I). For a brief over- 
Italian noble and native of Verona. He was born in Verona on 22 August 1720 as the Marquis of San Fermo and Sant Andrea. ${ }^{3}$ His father Orazio was the scion of an old Veronese noble family who through his marriage to Sagramoso's mother, Sofia von Bar from Hannover, was connected with the aristocracy of the Holy Roman Empire. ${ }^{4}$ Sagramoso's long and successful diplomatic career drew actively on both his extensive engagement with progressive thinkers and scholars of the day, and his role as a diplomat for an institution of the ancien régime and the esteem in which he was held in the most conservative courts of Europe.

The network of connections and relationships Sagramoso formed over the course of his career help to illustrate the processes which enabled the development and transmission of ideas of the Enlightenment. Ironically, these same personal networks were critical to the success of his most famous diplomatic mission, one that was initiated and orchestrated by the conservative forces of the Order of Malta and the absolute monarchies of Russia, Prussia and Austria. This was Sagramoso's embassy to the Polish court at the directive of the Grand Master of the Order of Malta in order to recover the long-contested bequest of Prince Janusz Ostrogski.

The courts of Russia, Prussia and Austria aimed to neutralise the existential threat posed by the Polish-Lithuanian Commonwealth (Poland), and further territorial ambitions. 5 Poland in the eighteenth century was governed by a parliamentary noble-democracy, with an elected monarch. Some of its citizen-nobles had largely embraced the progressive ideas propagated across Europe, and uniquely, took action through a number of government reforms inspired by principles of the Enlightenment, including the creation of Europe's first (and secular) ministry of education.

I will argue that Sagramoso's efforts to secure the Duchy of Ostrog for the Order, timed to coincide with the forced negotiation of the Treaties of Partition in I773, significantly contributed to pressure on the Polish Parliament, contributing to its capitulation. The First Partition resulted in annexation of one third of Polish

view of the Order's history see: Darius von Güttner-Sporzyński, "Evolution and Adaptation: the Order fo Saint John in War and Peace," Ordines Militares Colloquia Torunensia Historica. Yearbook for the Study of the Military Orders I 3 (2013): 205-2 17.

3 Aurelio Bertola, Vita del marchese Michele Enrico Sagramoso, Bali' del S. M. Ordine di Malta (Pavia: Presso Galeazzi, I793), 3.

4 On the family of Sagramoso see: Gustavo Oneto, Mille anni di storia della famiglia Sagramoso (Milano: Pinelli, I 938). Also Eros Maria Luzzitelli, Ippolito Pindemonte e la fratellanza con Aurelio de' Giorgi Bertola tra Scipione Maffei e Michele Enrico Sagramoso: una nuova questione sulle origini della Massoneria in Italia, con appendice di carteggi e documenti inediti (Verona: Libreria Universitaria, 1987), 46 no. 33; Giorgio Borelli, Un patriziato della terraferma veneta tra XVII e XVIII secolo: ricerche sulla nobiltà veronese (Milano: A. Giufffre, I 974), 303-3 I 5.

5 In this article I refer to the "Polish-Lithuanian Commonwealth" as "Poland". 
territory by Poland's neighbours. Prussia annexed $36,000 \mathrm{~km}^{2}$, home to 580,000 inhabitants (connecting Prussian territories along the Baltic, and taking Poland's access to the sea), Austria took $83,000 \mathrm{~km}^{2}$ with 2.7 million inhabitants, and Russia took $92,000 \mathrm{~km}^{2}$ with $\mathrm{I} .3$ million inhabitants. ${ }^{6}$ In the eyes of the reading public of Poland, Sagramoso and the Order of Malta had aided and abetted the "ce grand crime politique".?

\section{Michele Enrico Sagramoso}

Michele Enrico Sagramoso was a typical example of a European enlightened grandee of the age of the Grand Tour. "Hailed by Diderot as the father of travellers" Sagramoso remained "the guest who never overstayed his welcome at the courts of Europe." In his youth he developed taste and broad horizons, travelling across Europe, mingling with scientists, famous explorers, and the rich and powerful at many European courts. Sagramoso acquired a reputation as a man with great diplomatic skill, with excellent cultural sensitivity and impeccable manners. His diplomatic career benefited from great personal charm and an easiness of establishing personal rapport.

Initially, through his travels, and later, by a way of introduction, he established a large and noteworthy network of correspondents who formed the metaphysical Republic of Letters, an intellectual community which transcended political, linguistic and cultural boundaries. ${ }^{9}$ Wherever Michele Enrico Sagramoso ventured he was received not only as an erudite recommended by the progressive and learned, but also as an envoy of the Order of Malta. Paradoxically, noting his travels took place at the end of the eighteenth century, Sagramoso's credentials were both as a man of the Enlightenment and as a professed member of a Catholic religious institution reserved for the nobility. It was the combination of these that assured his success. ${ }^{10}$

6 Historia Polski w liczbach: ludność, terytorium (Warszawa: Główny Urząd Statystyczny, I 994), 20.

7 Henry Bonfils and Paul Fauchille, Manuel de droit international public (droit des gens) (Paris: A. Rousseau, I 908, 5 th edition), 43.

8 David F. Allen, "A Knight Hospitaller's Nostalgia for Italy during the I790s," The Electronic British Library Journal (2006): 9.

9 Dena Goodman, The republic of letters: a cultural history of the French enlightenment (Ithaca: Cornell University Press, I 994), 2.

Io The account of the most notable events of Michele Enrico Sagramoso's life and actions in the service of the Order of Malta, are known from the detailed account Life of the Marquis Michele Enrico Sagramoso, Bailiff of Sovereign Military Order of Malta, written by his long-time friend 
The institution Sagramoso represented, the Order of Malta was founded before the Crusades and was considered a stalwart of the ancien régimes of Europe. The Order's motto "Tuitio fidei et obsequium pauperum", "defence of the faith and assistance to the poor" proclaimed its mission as an international Catholic hospitaller institution; the mission remnant of its role as a protector of Christian pilgrims in the Holy Land. By the middle of the eighteenth century the Order continued to maintain an extensive system of property holding commanderies and its mission was supported by a diplomatic network capitalising on the social connections of its members. ${ }^{11}$

According to Aurelio Bertola, Michele Enrico Sagramoso was received into the Order of Malta before his 20 birthday and undertook the customary military training and service on the Order's galleys. ${ }^{12}$ His diplomatic training began soon after when in 174I he accompanied the Marquis de Castellane, an Ambassador of the Kingdom of France, to Constantinople..$^{13}$ After seven months in Constantinople, Sagramoso returned to Malta and then departed for Spain and Portugal, staying three months in Lisbon.

The first of the northern voyages of Sagramoso was undertaken at the behest of the Grand Master Manuel Pinto da Fonseca (r. I74 I-I 773), who in I 744 sent

and correspondent Aurelio De' Giorgi Bertola (1 $753-1798$ ). Bertola's account of Sagramoso's life corroborated by archival evidence enables the establishment of a detailed and vivid portrait. Bertola published the first volume of the account of Sagramoso's travels in I 793, two years after Sagramoso's death. See: Bertola, Vita, passim. For details of the relationship between Bertola and Sagramoso as well as the leading Italian members of the freemasonry, such as Ippolito Pindemonte and Francesco Scipione, see: Luzzitelli, Ippolito.

is For an analysis of the impact of the Enlightenment on the Order in the final years of the eighteenth century, see generally: Frans Ciappara, Enlightenment and reform in Malta, 1740-1798 (Sta. Venera: Midsea Books, 2006); also Victor Mallia-Milanes, "A Living Force of Continuity in a Declining Mediterranean: The Hospitaller Order of St John in Early Modern Times," in Mediterranean Identities - Environment, Society, Culture, ed. Borna Fuerst-Bjeliš (S.I.: IntechOpen, 2017), 29.

12 Bertola, Vita, 6. The date of Sagramoso's profession as a Knight of Malta is given as i 8 May I 740 in Francesco Bonazzi, Elenco dei cavalieri del S.M.ordine di S. Giovanni di Gerusalemme ricevuti nella veneranda lingua d'Italia dalla fondazione dell' ordine ai nostri Giorni, vol. 2 (Napoli: Detken \& Rocholl, I 907), I 93; cf. Federico Chesi, Michele Enrico Sagramoso: il carteggio, i viaggi, la massoneria (Verona: QuiEdit, 20 I 2), 25 no. 3.

13 Michel-Ange de Castellane (1703-1782) served as the French ambassador to the Sublime Porte from I74I to I747, see: Jean-Louis Fougeret de Montbron, Le cosmopolite, ou le citoyen du monde (I750), ed. Édouard Langille (London: Modern Humanities Research Association, 2010), 62. For correspondence between Castellane and various dignitaries of the Order of Malta see: Alain Blondy, Documents consulaires lettres reçues par le chargé d'affaires du roi à Malte au XVIIIème siècle avec la collaboration de Jean Bérenger (Malte: Fondation de Malte, 20 I 4). 
Sagramoso as the Order's envoy to the Court of Russia. ${ }^{14}$ Sagramoso was received by Empress Elizabeth (r. I74 I- I 762) in a private audience..$^{15}$ Although the circumstances are unclear, Sagramoso was also introduced to the Grand Duchess Catherine, the future Catherine II (r. I 762-1 796). Catherine mentions Sagramoso in her Memoirs, providing an account of his first visit to St Petersburg. She related that whilst kissing her hand, Sagramoso slipped her a secret note from her mother. ${ }^{16}$ The connection with Catherine would have a profound impact on Sagramoso's life and brought him to Russia three more times: in 1748 , in 1773 and finally in 1775 . According to Catherine, the secret correspondence was in contravention of Empress Elizabeth's order. Sagramoso brought the letter at the bidding of his mother, a close confidante of Catherine's mother. ${ }^{17}$

The family connections played important part in Sagramoso's success as did financial support he received from his family. The question of who was financing these extensive travels emerges in the correspondence between Sagramoso and his friend Francesco Scipione di Maffei (1675-1755), a writer, an antiquarian and a fellow Veronese. Maffei, who a decade earlier had travelled widely through Europe himself (and was a member of the French Académie des Inscriptions et Belles Lettres and a Fellow of the Royal Society), persuaded Sagramoso's father to continue to support the young man's experiences. ${ }^{18}$ Sagramoso began to write the reports of his travels after his return to Italy from Russia in 1745 . Then, excited by

14 Marialuisa Ferrazzi, "Michele Enrico Sagramoso. Un cavaliere di Malta veronese alla corte di Elisabetta e Caterina," in Pietroburgo capitale della cultura russa, vol. I, ed. Antonella D’Amelia (Salerno: Università degli studi di Salerno, 2004), r09-134; Maciej Loret, Kościót katolicki a Katarzyna II, I772-1784 (Kraków: W. L. Anczyc, I910), 92-I I 8; Ludwig von Pastor, The History of the Popes ([Wilmington]: Consortium, I 952), I 62-220.

is Thomas Freller, "In search of a Mediterranean base: The order of St. John and Russia's great power plans during the rule of Tsar Peter the Great and Tsarina Catherine II," Journal of Early Modern History 8, no. I (2004): I I.

16 Mémoires de Catherine II écrits par elle-même texte établi et présenté par Dominique Maroger, Récits et souvenirs, ed. Dominique Maroger (Paris: Hachette, I 953), I 42.

17 Blondy, "Lordre," 737 no. 20. In general see also: Stefania Pavan-Pagnini, "Viaggi in Russia e in Polonia del conte Michele Enrico Sagramoso," Vita Veronese 32 (1979): 25-33; 86-92; I 42-I 50; $213-220$. Sagramoso's mother was a lady-in-waiting to Sophia Dorothea of Hanover (1687-1757), the mother of Frederick II (r. 1740-1786) and the sister of George II of Great Britain (r. 1727-1760).

18 Scipione Maffei, Epistolario, I700-I755, vol. 2, ed. Celestino Garibotto (Milano: A. Giuffrè, I 955), I 244. The financial support for Sagramoso's later missions was also given by the Holy See: Ferrazzi, "Michele," I I 9; see also: Chesi, Michele, 26-27. Maffei's collaborator JeanFrançois Séguier ( $1703-1784)$ a French archaeologist and epigraphist also became Sagramoso's correspondent. Their surviving correspondence was published by Luzzitelli, Ippolito, 163- I 99. Some other of Sagramoso's letters are stored in Verona, Biblioteca Civica, Carteggi busta 86-87; see also: Franco Riva, Il carteggio di Michele Enrico Sagramoso (Firenze: Edizioni Sansoni 
the scientific observation of nature, he climbed the Talèfre glacier on Mont Blanc shortly after. ${ }^{19}$

According to Sagramoso's biographer Aurelio Bertola, in 1746 Sagramoso undertook the Grand Tour which lasted about 6 years. Its itinerary included visits to the most important royal courts of Europe; he spent time in Munich, Kassel, Hanover, Hamburg, Copenhagen, Stockholm and St. Petersburg, Berlin, Dresden and also visited Leipzig, Frankfurt and Strasburg. After Germany, he visited Switzerland and then Holland, the Austrian Netherlands, England and France. ${ }^{20}$ His Grand Tour followed the same route taken by his father twenty years earlier. However where the senior culminated his travels in Hanover, Michele Sagramoso continued to travel north, through Hamburg for Denmark where he visited Flensburg, Augustenborg, and Nyborg on the Great Belt. On 4 September 1747 Sagramoso attended the coronation of Frederick V (r. 1746-1766) in Copenhagen. ${ }^{21}$ The Scandinavian journey continued in the final months of 1747 and early 1748 with a visit to Sweden, where he visited Stockholm, Uppsala, the silver mines in Västmanland, Solberg, travelled through Karlskrona, Östergötland and Upland. ${ }^{22}$ He planned travel to Lapland but this was cancelled due to ill health. ${ }^{23}$

The visit to Uppsala was particularly memorable and important to Sagramoso because in addition to meeting the naturalist Olof Celsius (1670-1756), the philosopher Samuel Klingenstierna (1698-1765), he also met with Carl Linnaeus (1707-1778), a botanist, physician, and zoologist, known as the "father of modern taxonomy." The friendship between the two men was to last. ${ }^{24}$ "I did

antiquariato, I 961); Stefania Pagnini, "II carteggio Sagramoso alla Biblioteca Capitolare di Verona," Vita Veronese 30, nos. I I - I 2 ( I 977): 3 I I - 322.

19 Claire É. Engel, Knights of Malta: A Gallery of Portraits (London: Allen \& Unwin, I 963 ), I 9.

20 Bertola, Vita, 25-30; Giambattista Carlo Giuliari, "Lettera del Signor Marchese Michele Enrico Sagramoso al Conte Ignazio Zanardi di Mantova," Nuova Serie di Aneddoti i 8 ( I 877): I 8. See overview of this extensive voyage in Renato G. Mazzolini, "Linnaeus and Michele Enrico Sagramoso, Knight of the Order of Malta," in Linnaeus in Italy: the spread of a revolution in science, ed. Marco Beretta and Alessandro Tosi, Uppsala studies in history of science 34 (Sagamore Beach: Science History Publications, 2007), 62.

${ }_{21}$ Bertola, Vita, 29-30; Giuliari, "Lettera," I I. For other details of the itinerary of Sacramoso's travel through Scandinavia see: Cristina Wis, "I viaggi nordici di Michele Enrico Sagramoso," Settentrione. Rivista di studi italo-finlandesi i 8 (2006).

22 Maffei, Epistolario, I700-I755, 2: I 203; Mazzolini, "Linnaeus," 62-69.

23 The surviving correspondence of Sagramoso with Francesco Scipione di Maffei, Giambattista Morgani and Giuseppe Torelli refers to Sagramoso's problems with his eyes; see: Chesi, Michele, 3 I.

24 Mazzoni outlines in a great detail the network of scientific contacts and Sagramoso's interests: Mazzolini, "Linnaeus," 6I-75. Correspondence between Linnaeus and Sagramoso written between March and September 1748 survives as a part of the collection of The Linnaean cor- 
not know - observed Sagramoso about Linnaeus - another man more deeply and more passionately immersed in the sciences, and at the same time more inclined to society." ${ }^{25}$ When Sagramoso returned to Stockholm, he was admitted to the Academy of Sciences on 9 April 1748 on the recommendation of Carl Ehrenpreus (1692-1760), the Chancellor of the Privy Council. On I6 April Sagramoso gave a speech of acceptance in which he praised members of the Academy:

"Happy are the people who, under so enlightened leaders can begin a journey through the darkness of ignorance and prejudice, to acquire the illumination thanks to your discoveries, your research and your studies. May fate itself be favourable enough to provide some means to make me take part in it. This will be the main purpose of all my actions, so that the only reward to which I limit my ambition is to earn in my lifetime, a place in your memories and, after my death, a tomb in your annals."26

Sagramoso returned to Uppsala to visit Linnaeus again in May 1748 and before September he boarded a Swedish warship and headed to Russia. After taking part in constructing a nautical chart of the Nyland coast in Finland, Sagramoso landed in Vyborg on the Karelian Isthmus and from there continued to St. Petersburg. His second visit to the Russian Court was another diplomatic mission on behalf of the Order and perhaps the Holy See as well. The Grand Master Pinto da Fonseca recognised the increasing importance of Russia in European politics and in particular its influence in Central Europe. ${ }^{27}$ Pinto da Fonseca entrusted Sagramoso with persuading Empress Elizabeth to support the Order's petition to Frederick II of Prussia, requesting an extension of favourable tax concessions for the Order's estates in Silesia, a region which came under Prussian control during the War of the Austrian Succession (1740-1748). Sagramoso's visit was therefore aimed at more than just strengthening relations between Malta and the Russian Empire. ${ }^{28}$

Importantly for his successive missions to Poland and Russia, Sagramoso continued to remain in favour with the Grand Duchess Catherine and continued to facilitate her secret correspondence with her mother. Unaware of Sagramoso's duplicity, Empress Elizabeth was charmed by Sagramoso and on his departure

respondence, the Alvin Consortium, last modified 2019, accessed 21.07.2018. http://www. alvin-portal.org.

25 Bertola, Vita, 38.

26 Italian translation of the speech in Chesi, Michele, 3 I. The French text was printed in Riva, Il carteggio, 69-7 I.

27 Pavan-Pagnini, "Viaggi," 89.

28 Cf. Ferrazzi, "Michele," i I 2- I 6. Sagramoso most likely also negotiated the expansion of trade in wood used by the Order to build its fleet. 
showered him with gifts as well as specimens of plants, animals and minerals. ${ }^{29}$ From Russia his voyage took him to Germany, Holland and Switzerland where he remained nearly a year. In August of 1750 he crossed the Channel for England.

Sagramoso was recommended to British society by his friend Maffei, and in London he enjoyed the company of Frederick, Prince of Wales (1707-175 I). He visited Oxford and Cambridge. The tour of Britain took about a year and a half, and in October 175 I Sagramoso was already in France where he spent the next I 2 months touring the French provinces. ${ }^{30}$ Sagramoso met the philosophe Montesquieu at the castle La Brede and via Toulouse and Montpellier went to Lyon and Savoy. From there he went to Turin where he was received at court. His return to Verona marked the end of his Grand Tour in 1753.

Bertola gives a vivid account of Sagramoso's life at this time. Early in 1754 Sagramoso decided to settle in Venice where he led a life typical of a flamboyant aristocrat. Through his association with the Order of Malta he maintained his relationship with the Catholic milieu, yet he was also an enthusiast of the most progressive European intellectual trends. His time was divided between his official residence and his private quarters, where he entertained the Venetian intellectual and aristocratic elite. ${ }^{31}$ Sagramoso was found in the company of Francesco Algarotti and the future Doges of Venice, Marco Foscarini and Paolo Renier. Due to his growing reputation as an effective and skillful diplomat, in 1754 he was dispatched by the Order of Malta to the Court of Vienna and was received by Maria Theresa in a private audience..$^{32}$ Back in Venice, Sagramoso received a new appointment on 20 October 1760 as the Receiver of the Treasure for the Order of Malta in Venice. In the years that followed he negotiated a trade agreement between the Order of Malta and the Serenissima. ${ }^{33}$ For the next decade Sagramoso was absorbed with the affairs of the Order in Italy for which he traveled extensively. He was also involved in scientific experiments and innovation, especially in agriculture. In December 1769, after spending some time in Florence and Pisa he crossed the sea to Malta at the request of the Grand Master. ${ }^{34}$

29 Bertola, Vita, 54-6o; cf. Chesi, Michele, 37.

30 Bertola, Vita, 8 5-86.

31 Chesi, Michele, 44-45.

32 Bertola, Vita, io9.

33 Victor Mallia-Milanes, "A Man with a Mission: A Venetian Hospitaller on Eighteenth-Century Malta," in The Military Orders, vol. IV, On Land and By Sea, ed. Judi Upton-Ward (Aldershot-Burlington: Ashgate, 2008), 25 I-266.

34 Sagramoso's life in Venice and the subsequent events of his travels in Italy are discussed by Chesi who uses Sagramoso's letter collection to establish a precise itinerary, see: Chesi, Michele, 46-47. 
Grand Master Pinto da Fonseca outlined Sagramoso's new mission in early I 770 at the Order's headquarters on Malta. This mission would take Sagramoso back to Central Europe in order to recover the possession of lands (or at least the income due) from a bequest left by the Duke of Ostrog to the Order of Malta, in the form of the Entail of Ostrog. Sagramoso was also to settle the overdue payments from two existing Polish commanderies. ${ }^{35}$

\section{The Entail of Ostrog}

The Entail of Ostrog consolidated an immense landholding of the Ostrogski family and was established in 1609 by the richest magnate of Poland, Prince Janusz Ostrogski (1554-1620), Duke of Ostrog. ${ }^{36}$ Analysis of the inventory of the lands of the Entail and the wording of its founding Statutes suggests that Janusz Ostrogski aimed for the Duchy of Ostrog to became a defensive frontier march. ${ }^{37}$ The Statutes specified that the person inheriting the Entail was to maintain not

35 For the details of the eighteenth-century public discussion about the history and purpose of the Entail of Ostrog see the collection of pamphlets and documents published in Warsaw in 1754, "Akta publiczne do interessu ordynacyi Ostrogskiey należące." The "Affair of Ostrog" is also examined in great detail by Roderick Cavaliero based on the archival material from the Archives of the Order in Malta: Roderick Cavaliero, "The Affair of Ostrog. An Episode in Malto-Polish Relations in the Eighteenth Century," Journal of the Royal University of Malta 2 (I958): I 28-I4I.

36 Prince Janusz Ostrogski (1554-1620) was the last male descendant of the Ostrogski family. As a teenager he spent over five years at the imperial court of Vienna. He was raised as an Orthodox, but before I 577 , Janusz converted to Catholicism. Janusz held a number of strategically important appointments in the government of Poland including the highest office in Poland, the Castellany of Kraków. He was married three times: in 1582 with Zuzanna Seredy († I 596); in I 597 with Katarzyna Lubomirska (c. I58I-16II); in I6I 2 with Teofila Tarło (c. I 595-1635). In the first marriage, Janusz had two daughters. Eleonora who died in 16 I 8 as the wife of Prince Jan Jerzy Radziwilł and Eufrozyna who survived her father and was married to Prince Aleksander Zasławski. The Entail of Ostrog was held by the descendants of Eufrozyna as Eleonora died childless and the last male descendant of Janusz's sister, Prince Bogusław Radziwitł also died childless in I 669.

37 Stanisław Grodziski, Volumina Constitutionum, vol. 2, I550-I609 (Warszawa: Wydawnictwo Sejmowe, 2008), 385 ; T. Zielińska examines the institution of entail in Polish history: Teresa Zielińska, "Ordynacje w dawnej Polsce," Przeglad Historyczny 68, no. I (1 977): 17-30. A number of archival sources assist examination of Sagramoso's diplomatic mission to Warsaw are available in the Archives of the Order of Malta. These include correspondence between Sagramoso and the Grand Magistry as well as diplomatic communications between various European courts. Some of these are also published in Marialuisa Ferrazzi, "Il cavaliere melitense Michele Enrico Sagramoso e 'l'affare di Ostrog'. Note in margine alla storia dei rapporti polacco-maltesi del XVIII secolo," in Per Jan Slaski. Scritti offerti da magiaristi, polonisti, slavis- 
only a private army for the defence of Poland but also to upkeep the fortresses and strongholds within the Entail. The holder of the Entail had to be male and was to bear the dignity of Duke of Ostrog with its privileges and responsibilities. ${ }^{38}$ Janusz Ostrogski was survived by the descendants of his daughters, and left instructions that in the event that the daughters or their descendants died out, then the entail would pass to the Order of Malta. ${ }^{39}$ If the Order of Malta succeeded to the Entail of Ostrog, then Ostrogski required that it was to be held and managed by a Polish Knight of Malta and that the revenues and assets generated from it were to be used for the defence of Poland against raids from Tatars and Turks. ${ }^{40}$

The size of the bequest was staggering and for both the Order and the Polish nobles was a considerable prize. The Entail of Ostrog was about $\mathrm{I} 4,000 \mathrm{~km}^{2}$ (a half of modern Belgium or a half of the secularised Prussia in 1525$),{ }^{41}$ and included

ti italiani, ed. Andrea Ceccherelli et al. (Padova: Unipress, 2005), 93-I I6; Pavan-Pagnini, "Viaggi," passim.

38 “Ordynacya J. O. Xiążęcia Jmci Janusza Ostrogskiego, kasztelana krakowskiego," in Akta publiczne do interessu Ordynacyi ostrogskiey należace (Warszawa: s.n., I754).

39 The text of Janusz Ostrogski's statutes of the Entail of Ostrog are known from several acts of the Polish Parliament and pamphlets published in the course of the eighteenth century. Some of the copies are in Valetta, National Library of Malta, Archives of the Order of St. John of Jerusalem, of Rhodes and of Malta [hereinafter as: AOM]. Among the founding documents of the Entail there are the following: Approbatio Ordinationis Ostrowianae Excerpta ex Constitutionibus Comitiorum Generalium in Anno I 609 Varsoviae peractarum and Informatio circa ordinatione Ducatus Ostrogiensis. Actum Lublini in Judicis Ordinarii Generalibus, Tribunalis Regni, Arch. 47, I 45-I 64. In the Polish archives, for example, see the inventory of the estates of the Entail in: Spis dóbr do ordynacji należących, Kraków, Archiwum Państwowe, Archiwum Sanguszków, Teki Arabskie, ref. no. I30/36, pp. 73-79; Administracja Ordynacji Ostrogskiej, Wrocław, Zakład Narodowy Biblioteki im. Ossolińskich we Wrocławiu, ref. no. 3 I 3 , pp. 77 .

40 "Tranzakcja względem ludzi podług dyspozycji Rzpltej na obronę jej z dóbr Ordynacji Ostrogskiej należących," in Akta publiczne do interessu ordynacyi Ostrogskiey należące (Warszawa: s.n., 1754). For details of the 1753 "transaction of Kolbuszowa" which enumerates the division of the remnant of the Entail see: Kazimierz Waliszewski, Potoccy i Czartoryscy. Walka stronnictw i programów politycznych przed upadkiem Rzeczypospolitej I734-I763, vol. I, I734-I754 (Kraków: s.n., I 887), I 91-I 94. The estimated population of the Entail of Ostrog was 200,000. Mariusz Kowalski, "Wielkie posiadłości ziemskie w Rzeczypospolitej Obojga Narodów i ich wpływ na dzisiejsze środowisko antropogeniczne," Studia z Geografii Politycznej i Historycznej I (2OI 2): I I $3-\mathrm{I}_{3} 8$, here II 6 .

${ }_{41}$ Darius von Güttner-Sporzyński, "The End of Crusader State in Prussia: The Treaty of Kraków I 525 ," in Fighting for the Faith: the Many Crusades, ed. Kurt Villads Jensen, Carsten Selch Jensen, and Janus Møller Jensen, Runica et mediævalia. Scripta minora 27 (Stockholm: Stockholm University, 2018), 33 I-359. An estimated size of the Prussia in I 525 was 32,000 km²: Janusz Małłek, Ustawa o rządzie (Regimentsnottel) Prus Książęcych z roku I542: studium z dziejów przemian spotecznych i politycznych w lennie pruskim (Toruń: Państwowe Wydawnictwo Naukowe, 
approximately 24 cities, castles and towns, almost 600 villages, and generated an annual income of several hundred thousand ducats. ${ }^{42}$

In 1672 Aleksander Janusz Zasławski the last of Ostrogski's direct descendants died. Rather than pass to the Order however, the estates were appropriated by a number of relatives outside the scope of the original Entail, preventing the Order of Malta from gaining control. ${ }^{43}$ The Entail of Ostrog was treated as a family inheritance matter over the course of the next century until citizen-nobles were outraged by the division of the remnant lands by de facto landholder Prince Janusz Aleksander Sanguszko, bringing to an end the resourcing and maintenance of the defensive measures put in place by the original Entail of Ostrog. In 1753 Sanguszko entered into a transaction with several noble families (all noble-citizens and themselves or their family, members of Parliament) in which he divided and sold off portions of the Entail, effectively ending its existence as a legal entity. ${ }^{44}$

For a decade the beneficiaries of the transaction enjoyed the possession of the acquired lands and during the parliamentary session of 1766 used their influence in the Polish Parliament to endorse Sanguszko's transaction and dissolved the Entail without any compensation for the Order of Malta. Public opinion was placated by legislation requiring the owners of the lands of the former entail to pay the Crown Treasury the amount of 300 thousand ducats to maintain 600 soldiers. ${ }^{45}$

I 967), I 4. For estimates of the size of various estates of the Entail, see: Zbigniew Anusik, "Glosa do dziejów rodu książąt Ostrogskich," Przegląd Nauk Historycznych 7, no. I (2008): 20 I.

42 Tomasz Kempa, Dzieje rodu Ostrogskich (Toruń: Wydawnictwo Adam Marszałek, 2003), I 34. Anusik provides an in depth critique of Kempas approach to the history of the Dukes of Ostrog, and gives slightly different estimates which do not, however, diminish the scale of the estate, see: Anusik, "Glosa," I 77-178.

43 Jarosław Pietrzak gives a detailed outline of the events in the struggle between individual families to acquire control of the Entail of Ostrog by Aleksander Janusz Zasławski's mother and sister: Jarosław Pietrzak, "Walka Katarzyny z Sobieskich Radziwiłłowej o dobra ordynacji Ostrogskich w latach i 673-1678. Przyczynek do historii rozpadu latyfundium," Czasy nowożytne 26 (2013): 53-74.

44 Andrzej Rottermund, "Kawalerowie maltańscy w Polsce w XVIII i XIX wieku," in Zakon Maltański w Polsce, ed. Stefan Krzysztof Kuczyński (Warszawa: Wydawnictwo DiG, 2000), 9 I-95; "Konotacya Donacyi f. O. Xcia Sanguszka Marszałka Nadw. W. X. L. w Grodzie Sandomierskim Anno Domini 1753 poczynionych," in Akta publiczne do interessu ordynacyi Ostrogskiey należace (Warszawa: s.n., 1754).

45 For relevant legislation see: Volumina Legum, vol. 7, ed. Jozafat Ohryzko (Petersburg: Ohryzko Jozafat, I 860), 2 I 5-2 I 6; the narrative of the events is presented in Rottermund, "Kawalerowie," I I 4-I 22. 


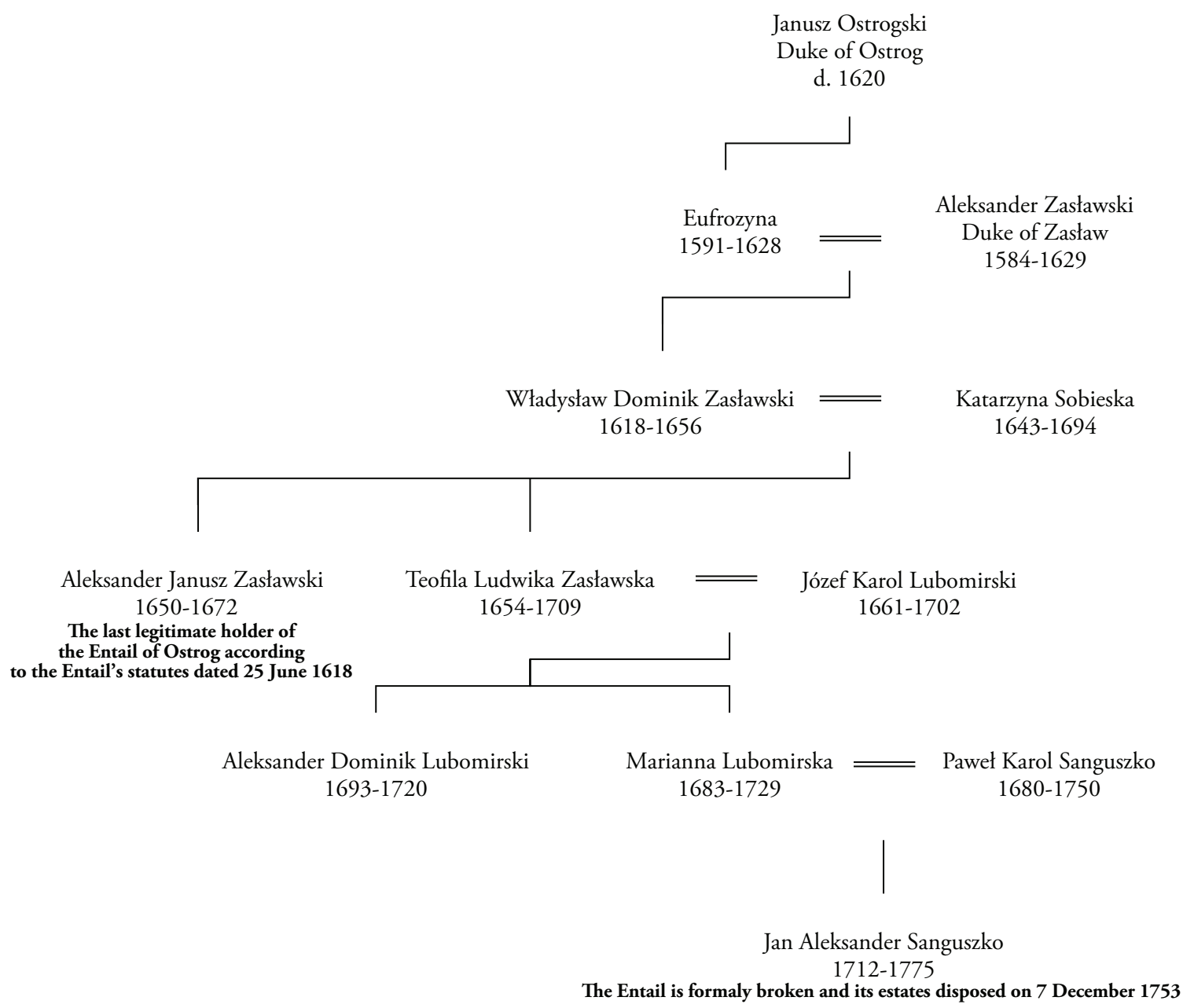

Figure I: The line of inheritance of the Entail of Ostrog by descendants of Prince Janusz Ostrogski.

\section{Poland, The Order of Malta and Sagramoso}

The two decades preceding Sagramoso's mission saw the blossoming of the Polish Enlightenment. ${ }^{46}$ During these decades an election for the king of Poland was held. Polish nobleman Stanisław Poniatowski (1732-1798) attained the throne in 1763 as Stanisław August, thanks to Russian support. Poniatowski was a prominent former lover of Catherine II, and contrary to the Empress's expectations, turned out to be a reformer. ${ }^{47}$ Stanisław August aimed to "dispel ignorance, bar-

46 Richard Butterwick, "The Enlighted Monarchy of Stanisław August Poniatowski ( 1764 - I 795 )," in The Polish-Lithuanian monarchy in European context c. I500-I795, ed. id. (Houndmills: Palgrave, 200 I).

47 On Stanisław Augustus's political ideas and vision of regenerated Poland, see: Richard Butterwick, Poland's last king and English culture: Stanislaw August Poniatowski, 1732-1798 (Oxford: Clarendon, I 998), ch. 7, I I and I 2. On the influence of the Enlightenment ideas on Poland, 
barity, poverty and fanaticism by reason, politeness, prosperity and tolerance." ${ }^{8}{ }^{8} \mathrm{In}$ the late 1760 s, Polish diplomatic efforts targeted France, Great Britain and Holland seeking to garner international support for Polish efforts to continue reform and for Poland to free itself from Russian domination. ${ }^{49}$ Polish conduct of international and domestic policy independent of the demands of Catherine II incensed Russia, otherwise preoccupied with its war with Turkey. ${ }^{5 \circ}$

When Grand Master Pinto da Fonseca formulated the scope of the mission entrusted to Sagramoso in 1770, European courts and their diplomatic networks were fully aware of the growing tensions between Russia and Poland as well as increased cooperation between Prussia and Austria (the latter being threatened by Russian advance into its sphere of influence in the Balkans). ${ }^{\text {sI }}$ During the summer of 1770 Russia gained the upper hand in the war with Turkey. Russia's improved position in European politics led to a rapprochement between Russia and Prussia, with the latter eager for territorial gains at the expense of Poland. ${ }^{52}$

During the first stages of Sagramoso's mission, and certainly before November I770, Catherine II had reached her decision to partition Poland in close collaboration with Prussia and Austria, an act which would cement Russia's influence over Polish affairs. ${ }^{53}$ The pretext for the partition of Poland was a Polish civil war and the failed attempt to kidnap King Stanisław August on 3 November 177 I

see Jerzy Michalski, Rousseau and Polish Republicanism, trans. Richard Butterwick-Pawlikowski (Warszawa: Instytut Historii PAN, 20 I 5 ).

48 Butterwick, "The Enlighted Monarchy," 2 i 5.

49 Dorota Dukwicz, "The internal situation in the Polish-Lithuanian Commonwealth (1769- I77 I) and the origins of the first partition," Acta Poloniae Historica, no. I03 (20 I I): 70.

so Poland and Lithuania were united in 1386 by a personal union of the crown and both countries shared the same monarch. In i 569 Poland and Lithuania entered into a constitutional union and established a common parliament. The union was known as "the Commonwealth of the Two Nations." By the end of the seventeenth century, the parliament became destabilised by factional infighting due to the institution of "liberum veto" which allowed any member of parliament to veto any legislation.

51 Pinto was already in correspondence with Catherine II, who in her letter of January I 768 assured him that her ambassador in Warsaw, Prince Nicholas Repnin (I734-I 80 I) was ordered to support the Order's claims by recommend the Order "to the justice of the Polish nation"; see: Blondy, "L'ordre," 736.

52 Dukwicz, "The internal situation," 76; see also: Richard Butterwick, The Polish Revolution and the Catholic Church, I788-I792 (Oxford: Oxford University Press, 20 I 2), 44; Jerzy Lukowski, Disorderly liberty: the political culture of the Polish-Lithuanian Commonwealth in the eighteenth century (London: Continuum, 2010), 95. The First Partition is analysed in detail in id., The partitions of Poland: 1772, I793, I795 (London: Addison Wesley Longman, I 998), I 52-1 97.

53 Dukwicz, "The internal situation," 83. 
by antiroyalist conspirators. ${ }^{54}$ These events were proclaimed by the diplomats of Russia, Prussia and Austria as proof of the inability of Poland to maintain order and internal unity.

Poland's neighbours aimed to "mask an act of conquest" by arguing that the partitioning of Polish territory would preserve the balance of power in Central and Eastern Europe. ${ }^{55}$ Moreover, the state of anarchy, they argued was a threat to their three neighbouring states and offended every notion of the Enlightenment. ${ }^{56}$ Russia, Prussia and Austria assured Europe, in the diplomatic offensive that accompanied these events, that they were the saviours of the Poland, painting it as a "stereotype of decay, failure and retribution." 57

The final decision to enforce the Partition of Poland was made in St. Petersburg

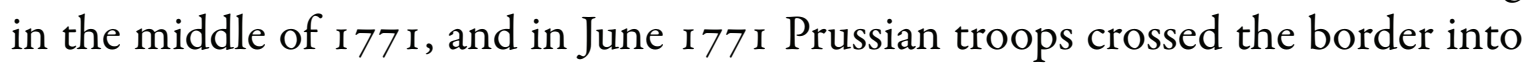
Poland, secure in assurances that Russia would not intervene (Russian troops had been stationed in Poland since the election King Stanisław August). Agreement between Russia and Prussia was secretly signed in St. Petersburg on 17 February I772; Austria endorsed the agreement two days later. ${ }^{58}$ The Partition Convention negotiated between the three countries was concluded in St. Petersburg and ratified officially 5 August 1 772. In September the monarchs notified King Stanisław August of their newly established pact via their ambassadors under the leadership of Otto Magnus von Stackelberg, the Ambassador of Russia. The diplomatic note advised their intention to annex Polish territory and demanded the convocation of the Poland's Parliament to endorse the partition with the legislature's approval.59

54 The rejection of Russian tutelage in the years which followed the election of Stanisław Augustus led to a civil war, known as the Confederacy of Bar which swept the country in I 768-1772. On the reforms and the actions of the king, see: Richard Butterwick, "The Enlighted Monarchy." passim.

ss Victor Kattan, "To Consent or Revolt? European Public Law, the Three Partitions of Poland ( 1772,1793 , and 1795 ) and the Birth of National Self-Determination," Journal of the History of International Law i 7, no. 2 (2015): 256.

56 In his political testament Frederick II asserted that Poland "could hardly be counted between the powers of Europe" because of "all the vices of the old feudal government [...]: elections of their kings, followed by civil wars, tumultuous diets, none of which survive, no legislation, no justice", see: Die Politischen Testamente der Hohenzollern, ed. Richard Dietrich (Köln: Böhlau, I 986), 626. Władysław Konopczyński, Dzieje Polski nowożytnej, vol. 2, ed. Jan Dzięgielewski and Mirosław Nagielski (Warszawa: Pax, I 986, 2nd edition), 632; Lukowski, Disorderly liberty, I09.

57 Lukowski, Disorderly liberty, I 2 I.

s8 Konopczyński, Dzieje Polski, 2: 632.

59 The ambassadors of Russia, Prussia and Austria worked according to the Projet d'un plan pour la conduite des trois ministres en Pologne. This "plan of action" prepared in St. Petersburg outli- 
In a climate of fear and with the King effectively a Russian hostage, in early I773, the King formally notified all European governments of the actions of Russia, Austria and Prussia and protested the violation of the sovereignty and territory of Poland. ${ }^{6}$ Yet in Europe, for all the talk of it being the Age of Reason, no one acted.

Sagramoso therefore commenced his diplomatic mission for the Order of Malta at a time of Polish national crisis. Before his arrival in Warsaw, Sagramoso prepared for his appointment to the Polish court by cautiously exploring the attitudes of the leading European courts towards the Order of Malta's claim to the lands of the Entail of Ostrog. ${ }^{61}$ Starting with London, Paris and Munich, Sagramoso "tested the waters" of foreign courts towards Poland, assessing his chance of persuading the Polish Parliament to reverse its earlier decisions unfavourable to the interests of the Order of Malta, taken years before in $1766 .{ }^{62}$ In January 1773 he was in Vienna. From there he went to Berlin via Prague and Dresden, where he was received by Frederick II of Prussia. He reached St. Petersburg in March and probably learned about the existence of a strong pro-Russian faction within the Polish Parliament there. In the course of his visits he was able to gauge the opinions of Poland's neighbours vis à vis the Order's objectives and also assessed the intentions of the partitioning powers in territorial terms. Based on his subsequent actions it appears that Sagramoso received assurances of support for his mission from Joseph II and Maria-Teresa of Austria, Frederick II and Catherine II. Sagramoso arrived in Warsaw on 17 April I 773, just days before the beginning of a parliamentary session convened under duress to ratify the Treaties of Partition with Russia, Prussia and Austria. The session lasted until April 1 775. ${ }^{63}$

Over the course of this two-year session, the Polish deputies and senators, held out on negotiations, sacrificing territory for Polish economic interests and guarantees of sovereignty. The Parliament in Warsaw met under the direct menacing

ned the key steps to be undertaken to break Poland, see: Dorota Dukwicz, Rosja wobec sejmu rozbiorowego warszawskiego (I772-I775) (Warszawa: Instytut Historii PAN, 2015 ), 76.

60 Lukowski, The partitions, 52-197.

${ }^{61}$ See, for example, Christian Heinrich von Keyserlingk, Lettres sur la negociation de l'affaire de Malthe en Pologne (Londres: s.n., I775).

62 Alain Blondy argues that the diplomatic action of the Order was relaunched at request of the French court, Blondy, "L'ordre," 732-767.

${ }_{63}$ Cavaliero, "The Affair," I 36; Dorota Dukwicz, "Restricted Sovereignty of the Sejm. The Plenipotentiary Delegation and Ratification of the First Partition Treaty, in Podziat wtadzy i parlamentaryzm w przesztości i wspótcześnie, ed. Wacław Uruszczak, Kazimierz Baran, and Anna Karabowicz (Warszawa: Wydawnictwo Sejmowe, 2007); Dukwicz, Rosja, 178-195; Andrzej Stroynowski, "Adam Poniński: marszałek sejmu i773-1775," Prace Naukowe Akademii im. Jana Dtugosza w Częstochowie. Zeszyty Historyczne I 5 (2016): I33-I 54, here 137. 
presence of Russian, Prussian and Austrian troops. Russia in particular expended great effort to achieve a façade of Polish approval of its actions, working hard to achieve legal, if entirely coerced Polish agreement to the Treaties of Partition and its enabling instruments. Via its agents in Parliament who controlled parliamentary procedure, and diplomatic and military threats, Russia orchestrated the division of the deputies into a smaller parliamentary commission to ensure compliance with its demands. ${ }^{64}$

The Court Circular confirms that Sagramoso was received for the first time by King Stanisław August on 3 May $1773 .{ }^{65}$ This was a diplomatic courtesy expected of the Order's envoy but Sagramoso also carried a personal letter from Catherine II to Stanisław August, in which the Empress recommended him as a person whom she has known for a long time, and whom she have always accorded her esteem. ${ }^{66}$ Next, Sagramoso approached Adam Poniński, who had just been elected the Speaker of the Parliament. Sagramoso knew that Poniński was already (through marriage) in control of some of the estates which comprised the Entail of Ostrog. ${ }^{67}$ More importantly, Sagramoso knew that Poniński was on the payroll of Russia and in direct contact with the Russian ambassador in Warsaw. ${ }^{68}$ Adam Poniński, characterised in the historiography of the period as the "most repulsive actor of the political life of the epoch" was the key asset for Russia in Warsaw. Poniński set up a special parliamentary commission for the task of expediting the negotiations of three separate Treaties of Partition between Russia, Prussia, Austria and Poland. The commission's work was ratified by the whole Parliament in September 1773. Whilst the whole Parliament had been convened, it was not allowed to debate the treaties which had been negotiated and endorsed by Poniński's parliamentary commission, but only to give its consent. ${ }^{69}$

Sagramoso suggested to Poniński that a family commandery (just patronatus) could be established on the lands of the Entail of Ostrog under Poniński's con-

64 Dukwicz, Rosja, 97-196.

65 Suplement do Wiadomości Warszawskich, May 25, 1773.

66 Cf. Ferrazzi, "Il cavaliere," I I I. Ferrazi gives the text of the undated letter from Catherine II to Stanisław August recommending Sagramoso and supporting his mission. In the letter sent from Warsaw and dated Io September 1773 Sagramoso thanked Catherine II for her support of his mission, see: Verona, The Biblioteca Civica, Carteggi busta 87.

${ }_{77}$ On the role of Adam Poniński as the leader of the pro-Russian party in the Polish Parliament, see: Stroynowski, “Adam Poniński: marszałek," I 33 - I 54.

68 Rottermund, "Kawalerowie," I 19.

69 Andrzej Stroynowski, “Adam Poniński w obradach delegacji sejmu i 773 - I 775," Prace Naukowe Akademii im. Jana Dtugosza w Częstochowie. Zeszyty Historyczne I7 (2018): 59-83, here 59. For the text of the Treaty, see: Clive Parry, The Consolidated treaty series, vol. 45 (Dobbs Ferry: Oceana Publications, 1969), 235-265. 
trol. Poniński's political career suggests that he might have desired an additional prestigious title. At the same time, Sagramoso calculated that, the lands under his control would provide some income payable to the Order's Treasury, making their use more in line with the original intention of Prince Janusz Ostrogski. Sagramoso persuaded Poniński, who as the Speaker of the Parliament, controlled the agenda and parliamentary proceedings, that the Order's official claim to the Entail of Ostrog should be debated during the current session of Parliament. After intervention from Sagramoso and pressure from ambassadors of Russia, Prussia and Austria exerted on the King Stanisław August, the issue of the Entail of Ostrog was placed on the Parliament's agenda. ${ }^{\circ}$ Sagramoso also published a short pamphlet the Deductio Jurium Kawalerów Maltańskich względem Ordynacyi Ostrogskiey which was distributed among the members of parliament and senators in which he reiterated the claim of the Order to the Entail of Ostrog. ${ }^{7}$

According to the Parliamentary Hansard Ostrog was first raised officially in response to Sagramoso's note on 9 October 1773 but debate was rejected by the members of Parliament. ${ }^{72}$ The ambassadors from the three neighbouring courts protested, insisting that the Order of Malta's claim to the Entail of Ostrog be debated and concluded as soon as possible. Polish deputies argued against hearing the claim, arguing that this was not the time to deal with it when Poland faced loss of its sovereignty and its territory. ${ }^{73}$ The Ambassadors pressured more. ${ }^{74}$ In the weeks that followed the deputies argued for and against allowing the Order to present its claim. A special committee was established and a procedural nightmare ensued. Sagramoso navigated carefully, courting those deputies who themselves were potentially in illegal possession of the estates of the Entail of Ostrog. On 23 November 1773 bishop Antoni Ostrowski, a collaborator of Poniński, after

70 Bertola, Vita, I 52.

${ }_{71}$ Michele Enrico Sagramoso, "Deductio Jurium Kawalerów Maltańskich względem Ordynacyi Ostrogskiey” (S.l.: s.n., I 766); cf. Relazione sopra l'Ordinazione di Ostrog, 23 July I 773, AOM 273, Lib. Conc. Stat., fol. I 4 r-v, i 5 r-v.

72 The Parliamentary Hansard: Protokót albo opisanie zasztych czynności na Delegacji od Stanów Rzeczypospolitej na Sejmie Extraordynaryjnym Warszawskim do zawarcia traktatów z dworami Wiedeńskim, Petersburskim i Berlińskim dnia Ig Maja roku 1773 wyznaczanej, a dnia Ig Marca roku 1775 zakończonej oraz cokolwiek mówiono, lub czytano byto, w wtaściwych każdego z JJ.OO Delegatów wyrazach wiernie spisany pod prezydencja J.W. Xiędza Antoniego Ostrowskiego Biskupa Kujawskiego i Pomorskiego porządkiem wszystkich sessji ręka jego podpisany, Zagajenia I-VII, ed. Aleksander Gurowski (Warszawa: Drukarnia Nadworna, I775); here: Session VII (9 October 1773), Protokót, II: 33-34.

73 Session VII (9 October 1773), Protokót, II: 34.

74 Session XII ( 15 October I 773), Protokót, II: 55; Session XIII ( 6 October 1773), Protokót, II: 63-7I. The Russian envoy stated politely that "he will await patiently, along with his colleagues, for a favourable response of the Polish deputies". 
a conference with Sagramoso, informed the Parliament of the anxiety expressed by "ambassadors of three courts in relation to the lack of information about works of the committee." The Poles, however, stood firm against Russian, Prussian and Austrian intimidation. ${ }^{75}$

Before the winter break of the Parliament of ${ }_{1773}$ Sagramoso intimated to the deputies that the Grand Master of the Order of Malta authorised him to cede all claims to the Duchy of Ostrog onto the Grand Prior of the Bailiwick of Brandenburg of the Order of Saint John (Herrenmeister), Price August Ferdinand of Prussia (1730-I 813 ), the brother of Frederick II.${ }^{76}$ Such a decision would enable Prussia to include the territory of the Entail of Ostrog in the negotiations of its Partition Treaty with Poland. The Deputies were threatened by this revelation, which opened the possibility of a protestant power acquiring large property deep within Poland. ${ }^{7}$

The Order of Malta's claim also became a subject of a public debate among the readers of pamphlets that flooded Warsaw. ${ }^{78}$ The Warsaw public deeply resented the Order of Malta's claim. Some pamphlets reminded readers that Poland had a rather unhappy experience with another military religious order, the Teutonic Knights. ${ }^{79}$

After several months of work of the parliamentary committee, the deputies received its report on I June $1774 .^{80}$ The Ambassador of Russia, dissatisfied with the lack of a concrete settlement in the report, reminded the deputies that his court and the courts of Vienna and Berlin expected the "matter of the Order of Malta justly concluded." ${ }^{81}$ In anticipation of the deadlock, Sagramoso, proposed a compromise on behalf of the Order of Malta. The Order was prepared, Antoni Sulkowski explained to the gathered deputies, to abandon its claim to the possession of the Duchy of Ostrog in exchange for a financial settlement with the

75 Session VIII (23 November 1773), Protokót, II: 93.

${ }_{76}$ For the summary of the proceedings see: Rottermund, "Kawalerowie," I 26-I30; also an overview in Cavaliero, "The Affair," I $37-138$.

77 The Partition Treaties ratified in September 1773 were followed by the negotiations of the constitutional reform of Poland and the trade treaties with the partitioning powers, Dukwicz, Rosja, 246-286.

78 Adam Poniński, the Speaker of the Parliament, was attacked for his greed and eagerness to fulfil demands of his Russian paymasters, Barbara Wolska, "Wierszowane pamflety polityczne na przywódców sejmu rozbiorowego (I773-I775)," Archiwum Literackie 25 (I 98 I ): 69- 106.

79 Rottermund, "Kawalerowie," I 2 I. The echoes of this polemic can be found in the writtings of Hugo Kołłątaj, Listy Anonima i Prawo polityczne narodu polskiego, vol. I (Warszawa: Państwowe Wydawnictwo Naukowe, I 954), 232.

80 Session X ( I June I 774), Protokót, IV: 59.

8r Session XVI (9 June I774), Protokót, IV: 97. 
families who de facto held the estates of the Entail. ${ }^{82}$ Given the focus on the Partition Treaties, Sagramoso started negotiations with individual magnate families who were usurping the Order of Malta's rights to the lands of Ostrog, noting that the majority of these families were represented in the Parliament by at least one deputy.

In May 1774 Sagramoso concluded an individual agreement with Adam Poniński. ${ }^{{ }_{3}}$ The Order of Malta renounced all claims to the lands (including towns and villages) in possession of Poniński, and in turn Poniński, became a commander of a hereditary commandery of the Order of Malta established on his estates, with the estimated value of 300 thousand Polish złoty and income of I 5 thousand per annum. ${ }^{84}$ Poniński was received into the Order of Malta as a commander and received a decoration of a Grand Cross from Sagramoso. It seems that Sagramoso hoped that the example of Poniński would encourage other Polish magnates to follow suit. ${ }^{85}$

Pressure was maintained to keep the Ostrog Entail on the parliamentary agenda. The ambassadors of Russia, Prussia and Austria were continuously present during the proceedings. Polish deputies however noted in the ensuing debate that Sagramoso was conducting negotiations behind the scenes and were concerned that these agreements would favour individual families and not Poland itself. The issue was again debated on 5 September and 14 September 1774 . The Polish king himself submitted a number of proposals but the deputies rejected them arguing that the Order of Malta is like any other religious institution in Poland unable to "inherit" property due to the law preventing the "dead hand" bequests. The Russian Ambassador intervened, and on his behalf the Speaker Adam Poniński reminded the assembled of the warning of the Prussian king's involvement. ${ }^{86} \mathrm{Sa}$ gramoso used the Russian and Prussian's Ambassadors influence again. After a series of stormy debates some deputies were ready for a compromise. ${ }^{87}$

In the end the Polish Parliament approved a settlement between the Order of Malta and Poland. On 2 December 1774 the deputies endorsed the 1766 and I 768 decisions of the Parliament which dissolved the Entail of Ostrog on con-

82 Ibid., 97-98.

83 Teresa Zielińska, "Poniński Adam," in Polski Stownik Biograficzny, vol. 27, ed. Emanuel Rostworowski (Wrocław: Zakład Narodowy im. Ossolińskich / Wydawnictwo Polskiej Akademii Nauk, I983): 504-5 I I. Poniński notified the Parliament of the agreement reached with the Order three months later. Session XLVI ( I September I 774), Protokót, IV: 32 I.

84 Rottermund, "Kawalerowie," I 27.

85 Ibid., I 28.

86 Protokót, IV: 344, 427; see: Rottermund, "Kawalerowie," I 30 ; Ferrazzi, “Il cavaliere," 98- 100.

87 Session XII (7 December I 774) Protokót, VI: 42-43, 5 I. 
dition that the landholders of the estates of the former Entail will pay the Polish Treasury 300 thousand Polish złoty for the maintenance of a substantial regiment. The act established the Order of Malta's Grand Priory of Poland with six commanderies. In addition, on 7 December an act endorsing establishment of eight family commanderies of the Order of Malta was approved. On behalf of the Order Sagramoso made a public declaration that the Order abandoned the claim to the Entail of Ostrog and instead accepted an annual responsium payable to the Order's treasure from the Grand Priory of Poland. ${ }^{88}$

In his report to the Grand Master, Sagramoso wrote that, it was

"impossible in a short report to [give the full account] of the innumerable correspondence with almost all the European courts. Of all strange and almost unbelievable events. And of these incredible solutions I was forced to employ in order to achieve the resolution of the matter. All those wanting, most bitter and ghastly disputes I had to participate in; insincere legal tricks and political intrigues, which in this report are at once difficult and too delicate to explain." ${ }^{89}$

Sagramoso succeeded in securing over 30 thousand ducats annual income for the Order by enmeshing the Order of Malta in the imperial ambitions of Russia, Prussia and Austria who aimed at containing ambitions of independent Poland. $\mathrm{He}$ was a pragmatic and he achieved what was possible at the time of his mission. "The Poles, whose national pride", wrote Roderick Cavalliero in a scathing reflection on the whole affair, "was too easily dissipated in empty shows, found a convenient way out of tedious litigation in which the three neighbouring powers threatened to intervene, and honour was satisfied all round." 90 At the same time a contemporary account highlighted the role of Sagramoso who "induced [the Poles] to value a black ribbon with a little cross [...] satisfying their greed and vanity." ${ }^{11}$

The envoy of the Order of Malta had exploited the insecurities of the deputies to the Polish Parliament, some direct beneficiaries of the dissolution of the Entail of Ostrog, during the turmoil of the foreign intervention and the direct military pressure exerted by Russia, Prussia and Austria.

88 Volumina Legum, vol. 8, ed. Jozafat Ohryzko (Petersburg: Ohryzko Jozafat, I 860), I 24- I 25; Andrzej Rottermund offers an extended discussion of this parliamentary session, Rottermund, "Kawalerowie," I32-1 34.

89 The account of his mission to Poland by Sagramoso was presented to the Grand Master on 22 May I 778, AOM, 273, Lib. Conc. Stat., fol. 173r-175v). Italian text published in Ferrazzi, "Il cavaliere," i I 4.

90 Cavaliero, "The Affair," I 38.

9 I Keyserlingk, Lettres, 80. 
Sagramoso left Warsaw on 27 June 1774 and travelled to St. Petersburg on another diplomatic mission, now for the Holy See. The Empress asked him to stay on in her service, but he excused himself from this great honour on the grounds of ill health, claiming that the two years of his mission in Poland had totally exhausted him. ${ }^{22}$ On his way from St. Petersburg Sagramoso stopped in Warsaw on 6 August 1776 and was received by the King. The "Gazeta Warszawska" informed that Sagramoso was present at the Court where the contents of the papal bull was announced confirming the establishment of the Grand Priory of Poland and formalising papal approval and resolution of the matter of the Entail of Ostrog. ${ }^{93} \mathrm{He}$ finally left Warsaw on 26 December 1776 and, via Wrocław and Prague returned to Malta where his efforts were recognised by the Grand Master. Sagramoso was awarded the dignity of a Bailiff Grand Cross and a generous pension. ${ }^{94}$

Sagramoso's return from Central Europe to Italy did not mark the end of his diplomatic activity. After he settled in Naples in 1778 , Sagramoso still travelled through Italy and served as an intermediary in relations between the Order of Malta and the Court of Naples. His knowledge of Russian affairs necessarily involved him in the management of the Order's diplomatic relations with Russia, in particular as Catherine II sought to involve the Order in an alliance against the Ottoman Empire.95 He died in Naples on 9 March 179 I.

92 More on Sagramoso diplomatic mission in Russia can be found in Chesi, Michele, 5 I- 52 ; Ferrazzi, "Michele," I 24- I 26; Loret, Kościót, 92 - i 8.

93 Gazeta Warszawska, io August 1776, I. The Archives of the Grand Priory of Poland are now in the collection in Warsaw, Biblioteka Uniwersytetu Warszawskiego, Dział Rękopisów, ref. no. I33, Papiery Maltańskie I 774- I 794. The collection consists of over 500 letters and documents of the secretary of the Grand Priory Gaetano Ghigiotti. Another collection, which includes letters of Sagramoso is stored in Warsaw, Archiwum Główne Akt Dawnych, Archiwum Ghigiottiego, I $760-$ I 798 , PL, I i 5 , ref. no. 644 .

94 Elevation of Sagramoso to the rank of Bailiff, AOM, I 530, Lib. Conc. Stat., fol. 96v-97r; AOM, 580 , Lib. Conc. Stat., fol. $304 \mathrm{r}-\mathrm{v}$ and fol. I $44 \mathrm{r}-\mathrm{v}$. The pension, AOM, 273, Lib. Conc. Stat., fol. $172 \mathrm{v}-\mathrm{I} 73 \mathrm{r}$.

95 On his retirement, see: Ferrazzi, “Michele," I 29. 


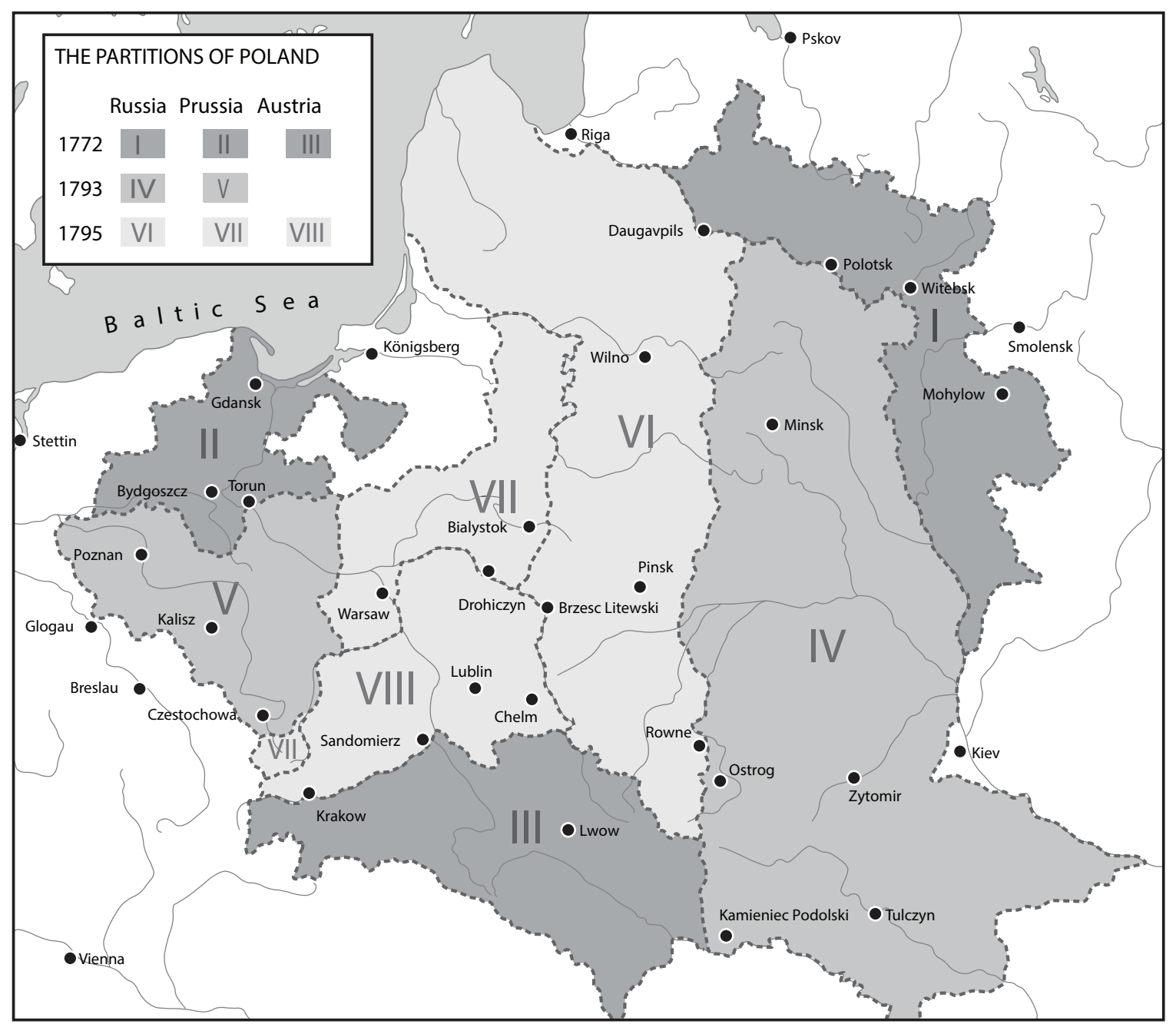

Figure 2: The three partitions of Poland.

\section{Conclusion}

The nature of Sagramoso's Polish mission and his career as a diplomat of the Order of Malta reflected the changing character of the Order in the eighteenth century. From an organisation focused on the defence of Christendom and service to the sick, the Order became an institution entangled in the European web of alliances and political strategies and notably the First Partition of Poland. The knights of Malta, such as Sagramoso, who were members of the European nobility and pillars of the ancien régimes, undertook the roles of courtiers and diplomats travelling across the continent but also taking part in the pursuits of their peers dominated by new trends. Sagramoso's membership of the Order of Malta and his involvement in the advancement of the ideas of the Enlightenment demonstrate the irony 
of history. The institutions of the European ancien régimes were not undermined from without but very much from within. The knights were unwilling or unable to counter the increasing secularisation of European society. They could not be at the same time both infused with the ideal of the Enlightenment with its rejection of organised religion and the pursuit of the cult of reason and be faithful to the Catholic ethos demanding that the knights serve the poor and sick not only to secure their salvation, but because the person cared for represented the person of Christ.

For Poland, the period of the Sagramoso mission marked the end of the beginning of the tumultuous years of reform led by King Stanisław August focused on education, culture and national regeneration. In his attempt to salvage the bequest of Prince Janusz Ostrogski, for the benefit of the Order, Sagramoso demonstrated the most arcane of diplomatic skills. His actions ultimately benefited Russia, Prussia and Austria, who used the threat of military intervention to achieve the legalisation of the annexation of Polish territory. The machinations of the partitioning powers, it seems in active coordination with Sagramoso, to force the debate and decide the claim to the Entail of Ostrog by the Order of Malta, appear to have been orchestrated as part of the campaign to secure Polish legal agreement to the Partition Treaties. Sagramoso, in achieving the aims of his embassy implicated the Order of Malta in "the most flagrant violation of natural justice and international law" 96 , the first partition of Poland.

Many questions for future research remain. Was the mission to Poland for the recovery of Ostrog part of a long-term plan to shore up the ancien régimes and recover a valuable asset, for which Sagramoso was deliberately prepared and trained? Or, was the Order of Malta opportunistic, treating the Polish crisis as a good time to secure a lost asset, finding in Sagramoso a talented, well-connected nobleman with natural curiosity of things scientific? Was Sagramoso a freemason, as were many of his interlocutors, including Adam Poniński (and if so, what was their agenda!)? Did the Order of Malta act independently in its renewal of the claim to the Entail of Ostrog or, was the Order a tool used by the partitioning powers to help achieve control of Poland? Who, amongst the Polish nobility, ultimately benefited from the dissolution of the Entail and what did they give in return?

Adam Poniński was tried and convicted a traitor in 1790 for his leading role during the parliamentary session of $1772-1795$, collaboration with the partitioning powers, and for corruption. Poniński was sentenced to forfeiture of his dignities including his title, nobility, as well as his family name, and was banished

96 Henry Wheaton, History of the law of nations in Europe and America (New York: Gould, Banks \& Co., I 845), 269. 
from Poland. The Grand Priory of Poland created during Sagramoso's mission was tarnished by its association with the traitor. The Priory only lasted 20 years and ceased to exist after the Third (and final) Partition of Poland in I 795. The Order of Malta did not regain popularity in Poland and the Order entered a period of decline across Europe.

The First Partition of Poland is considered a national tragedy by Poles. ${ }^{97}$ The experience would be repeated however, in Poland and elsewhere. Within ten years of Sagramoso's mission to Poland the Order faced the consequences of the French Revolution with expulsion from their headquarters on the Island of Malta. Sagramoso's assistance rendered to Catherine II, enabled the Empress to finesse Russia's "facts on the ground". Annexation of the last remaining territories of Poland came in 1795, led by Russia and supported by Prussia and Austria. The Order of Malta was subjected to similar treatment when Catherine's son, Paul I, took over in I 799. In the end, whilst Sagramoso's mission was hailed as a success, the responsium payable by the Grand Priory of Poland looks more like 30 pieces of silver.

\section{PRIMARY SOURCES:}

Kraków. Archiwum Państwowe, Archiwum Sanguszków, Teki Arabskie, ref. no. 130/36. Valetta. National Library of Malta, The Archives of the Order of St John of Jerusalem, of Rhodes and of Malta, Arch. 47; 273, 580 and I 530, Lib. Conc. Stat.

Verona. Biblioteca Civica, Carteggio di Michele Enrico Sagramoso, Carteggi busta 87.

Warszawa. Archiwum Główne Akt Dawnych, Archiwum Ghigiottiego, 1760-1798, PL, I I 5 , ref. no. 644 .

Warszawa. Biblioteka Uniwersytetu Warszawskiego, ref. no. I33, Papiery Maltańskie I774-I 794 .

Wrocław. Zakład Narodowy Biblioteki im. Ossolińskich we Wrocławiu, ref. no. 3 I 3.

Akta publiczne do interessu ordynacyi Ostrogskiey należace. Warszawa: [s.n.], I754.

Bertola, Aurelio. Vita del marchese Michele Enrico Sagramoso, Bali del S. M. Ordine di Malta. Pavia: Presso Galeazzi, 1793.

Bonazzi, Francesco. Elenco dei cavalieri del S.M.ordine di S. Giovanni di Gerusalemme ricevuti nella veneranda lingua d'Italia dalla fondazione dell' ordine ai nostri Giorni. Vol. 2. Napoli: Detken \& Rocholl, 1907.

Bonfils, Henry, and Paul Fauchille. Manuel de droit international public (droit des gens). Paris: A. Rousseau, I 908, 5 th edition.

Gazeta Warszawska, io August 1776.

97 William Hall refers to it as "immoral act of appropriation", see: William Hall, $A$ treatise on international law (Oxford: Clarendon Press, I 904), I I 9; Zielińska, "Poniński," 508-5 I I. 
Keyserlingk, Christian Heinrich von. Lettres sur la negociation de l'affaire de Malthe en Pologne. Londres: s.n., I 775.

The Linnaean correspondence. The Alvin Consortium. Last modified 2019. Accessed 21.07.20 18. http://www.alvin-portal.org.

Maffei, Scipione. Epistolario, I700-I755. Vol. 2. Edited by Celestino Garibotto. Milano: A. Giuffrè, I 955.

Mémoires de Catherine II écrits par elle-même texte établi et présenté par Dominique Maroger. Récits et souvenirs. Edited by Dominique Maroger. Paris: Hachette, I 953.

Die Politischen Testamente der Hohenzollern. Edited by Richard Dietrich. Köln: Böhlau, I 986.

Protokót albo opisanie zasztych czynności na Delegacji od Stanów Rzeczypospolitej na Sejmie Extraordynaryjnym Warszawskim do zawarcia traktatów z dworami Wiedeńskim, Petersburskim i Berlińskim dnia Ig Maja roku I773 wyznaczanej, a dnia Ig Marca roku I775 zakończonej oraz cokolwiek mówiono, lub czytano byto, w wtaściwych każdego z JJ.OO Delegatów wyrazach wiernie spisany pod prezydencja J.W. Xiędza Antoniego Ostrowskiego Biskupa Kujawskiego i Pomorskiego. porządkiem wszystkich sessji ręka jego podpisany. Edited by Aleksander Gurowski. Zagajenia I-VII, Warszawa: Drukarnia Nadworna, I 775.

Sagramoso, Michele Enrico. Deductio Jurium Kawalerów Maltańskich względem Ordynacyi Ostrogskiey. [S.1.: s.n.], I 766.

Suplement do Wiadomości Warszawskich, May 25, 1773.

Volumina Constitutionum. Vol. 2. I587-I609. Edited by Stanisław Grodziski. Warszawa: Wydawnictwo Sejmowe, 2008.

Volumina Legum. Vol. 7-8. Edited by Jozafat Ohryzko. Petersburg: Ohryzko Jozafat, I 860.

Zebranie skryptow y listow roznych tyczacych się okoliczności Ordynacyi Ostrogskiey. S.l: s.n. [ 1754$]$.

Memoires de Stanislas II Auguste. Edited by Anna Grześkowiak-Krwawicz and Dominique Triaire. Paris: Institut d'Etudes Slaves, 20 I 2.

\section{SeCondary SOURCES:}

Allen, David F. “A Knight Hospitaller's Nostalgia for Italy during the I 790 os." The Electronic British Library Journal (2006): I - I 2.

Anusik, Zbigniew. “Glosa do dziejów rodu książąt Ostrogskich.” Przegląd Nauk Historycznych 7, no. I (2008): 1 27-2 I0.

Blondy, Alain. Documents consulaires lettres reçues par le chargé d'affaires du roi à Malte au XVIIIème siècle avec la collaboration de Jean Bérenger. Malte: Fondation de Malte, $20 \mathrm{I} 4$.

Blondy, Alain. "L’ordre de Malte et Malte dans les affaires polonaises et russes au XVIII siècle." Revue des études slaves 66, no. 4 (I 994): 733-755.

Borelli, Giorgio. Un patriziato della terraferma veneta tra XVII e XVIII secolo: ricerche sulla nobiltà veronese. Milano: A. Giufffrè, I 974. 
Butterwick, Richard. Poland's last king and English culture: Stanislaw August Poniatowski, 1732-1798. Oxford: Clarendon, I 998.

Butterwick, Richard. The Polish Revolution and the Catholic Church, I788-I792. Oxford: Oxford University Press, $20 \mathrm{I} 2$.

Butterwick, Richard. "The Enlighted Monarchy of Stanisław August Poniatowski ( $1764-$ -1795)." In The Polish-Lithuanian Monarchy in European Context, c. I500-I795, edited by Richard Butterwick, I 93-2 I 8. Houndmills: Palgrave, 200 I.

Cavaliero, Roderick. "The Affair of Ostrog. An Episode in Malto-Polish Relations in the Eighteenth Century." Journal of the Royal University of Malta 2 ( I 958): I 28-I 4I.

Chesi, Federico. Michele Enrico Sagramoso: il carteggio, i viaggi, la massoneria. Verona: QuiEdit, 20 I 2.

Ciappara, Frans. Enlightenment and reform in Malta, 1740-I798. Sta. Venera: Midsea Books, 2006.

Goodman, Dena. The republic of letters: a cultural history of the French enlightenment. Ithaca: Cornell University Press, 1994.

Dukwicz, Dorota. "The internal situation in the Polish-Lithuanian Commonwealth (1769-177I) and the origins of the first partition: (in the light of Russian sources)." Acta Poloniae Historica I 03 (20 I I ): 67-84.

Dukwicz, Dorota. "Restricted Sovereignty of the Sejm. The Plenipotentiary Delegation and Ratification of the First Partition Treaty." In Podziat wtadzy i parlamentaryzm w przesztości i wspótcześnie, edited by Wacław Uruszczak, Kazimierz Baran, and Anna Karabowicz, 454-467. Warszawa: Wydawnictwo Sejmowe, 2007.

Dukwicz, Dorota. Rosja wobec sejmu rozbiorowego warszawskiego (I772-I775). Warszawa: Instytut Historii PAN, 2015.

Engel, Claire É. Knights of Malta: A Gallery of Portraits. London: Allen \& Unwin, I 963. Ferrazzi, Marialuisa. "Il cavaliere melitense Michele Enrico Sagramoso e 'l'affare di Ostrog'. Note in margine alla storia dei rapporti polacco-maltesi del XVIII secolo." In Per Jan Slaski. Scritti offerti da magiaristi, polonisti, slavisti italiani, edited by Andrea Ceccherelli, Danilo Gheno, Andrzej Litwornia, Marcello Piacentini, and Anton Maria Raffo, 93-I I 6. Padova: Unipress, 2005.

Ferrazzi, Marialuisa. "Michele Enrico Sagramoso. Un cavaliere di Malta veronese alla corte di Elisabetta e Caterina." In Pietroburgo capitale della cultura russa. Vol. I, edited by Antonella D’Amelia, ı 09-I 34. Salerno: Università degli studi di Salerno, 2004.

Fougeret de Montbron, Jean-Louis. Le cosmopolite, ou le citoyen du monde (I750). Edited by Édouard Langille. London: Modern Humanities Research Association, 20 I 0.

Freller, Thomas. "In search of a Mediterranean base: The order of St. John and Russia's great power plans during the rule of Tsar Peter the great and Tsarina Catherine II." Journal of Early Modern History 8, no. I (2004): 3-30.

Giuliari, Giambattista Carlo. "Lettera del Signor Marchese Michele Enrico Sagramoso al Conte Ignazio Zanardi di Mantova." Nuova Serie di Aneddoti i 8 ( I 877): 7- I 8.

von Güttner-Sporzyński, Darius. "Evolution and Adaptation: the Order fo Saint John in War and Peace." Ordines Militares Colloquia Torunensia Historica. Yearbook for the Study of the Military Orders I 3 (2013): 205-2 I 7. 
von Güttner-Sporzyński, Darius. "The End of Crusader State in Prussia: The Treaty of Kraków i 525." In Fighting for the Faith: the Many Crusades, edited by Kurt Villads Jensen, Carsten Selch Jensen, and Janus Møller Jensen, 33 I-359. Runica et mediævalia. Scripta minora 27. Stockholm: Stockholm University, 20 I 8.

Hall, William. A treatise on international law. Oxford: Clarendon Press, I 904.

Historia Polski w liczbach: ludność, terytorium. Warszawa: Główny Urząd Statystyczny, I 994.

Kattan, Victor. "To Consent or Revolt? European Public Law, the Three Partitions of Poland (1772, I 793, and I 795) and the Birth of National Self-Determination." Journal of the History of International Law I 7, no. 2 (20 I 5): 247-28 I.

Kempa, Tomasz. Dzieje rodu Ostrogskich. Toruń: Wydawnictwo Adam Marszałek, 2003.

Kołłątaj, Hugo. Listy Anonima i Prawo polityczne narodu polskiego. Vol. I. Warszawa: Państwowe Wydawnictwo Naukowe, 1954.

Konopczyński, Władysław. Dzieje Polski nowożytnej. Vol. 2. Edited by Jan Dzięgielewski and Mirosław Nagielski. Warszawa: Pax, i 986, 2nd edition.

Kowalski, Mariusz. "Wielkie posiadłości ziemskie w Rzeczypospolitej Obojga Narodów i ich wpływ na dzisiejsze środowisko antropogeniczne.” Studia z Geografii Politycznej i Historycznej I (20 I 2): I I 3- I 38.

Loret, Maciej. Kościót katolicki a Katarzyna II, I772-1784. Kraków: W. L. Anczyc, I 9 I 0.

Lukowski, Jerzy. Disorderly liberty: the political culture of the Polish-Lithuanian Commonwealth in the eighteenth century. London: Continuum, 2010.

Lukowski, Jerzy. The partitions of Poland: 1772, 1793, 1795. London: Addison Wesley Longman, 1998.

Luttrell, Anthony. "From Jerusalem to Malta: The Hospital's Character and Evolution." In Peregrinationes: Acta et Documenta. Vol. I, edited by Accademia Internazionale Melitense. Conference, 13-22. Malta: Accademia Internazionale Melitense, 2000.

Luzzitelli, Eros Maria. Ippolito Pindemonte e la fratellanza con Aurelio de' Giorgi Bertola tra Scipione Maffei e Michele Enrico Sagramoso: una nuova questione sulle origini della Massoneria in Italia, con appendice di carteggi e documenti inediti. Verona: Libreria Universitaria, I 987.

Mallia-Milanes, Victor. "A Man with a Mission: A Venetian Hospitaller on Eighteenth-Century Malta." In The Military Orders. Vol. IV, On Land and By Sea, edited by Judi Upton-Ward. 25 I-266. Aldershot-Burlington: Ashgate, 2008.

Mallia-Milanes, Victor. "A Pilgrimage of Faith, War, and Charity: The Order of the Hospital from Jerusalem to Malta." In Religion, ritual and mythology: aspects of identity formation in Europe, edited by Joaquim Carvalho, 83-96. Pisa: Pisa University Press, 2006.

Mallia-Milanes, Victor. "A Living Force of Continuity in a Declining Mediterranean: The Hospitaller Order of St John in Early Modern Times." In Mediterranean Identities - Environment, Society, Culture, edited by Borna Fuerst-Bjeliš, 27-45. S.l.: IntechOpen, 20 I 7 .

Małłek, Janusz. Ustawa o rządzie (Regimentsnottel) Prus Książecych z roku I542: studium $z$ dziejów przemian spotecznych i politycznych w lennie pruskim. Toruń: Państwowe Wydawnictwo Naukowe, i 967. 
Mazzolini, Renato G. "Linnaeus and Michele Enrico Sagramoso, Knight of the Order of Malta." In Linnaeus in Italy: the spread of a revolution in science, edited by Marco Beretta and Alessandro Tosi, 6 I-75. Uppsala studies in history of science 34. Sagamore Beach: Science History Publications, 2007.

Michalski, Jerzy. Rousseau and Polish Republicanism. Translated by Richard Butterwick-Pawlikowski. Warszawa: Instytut Historii PAN, 2015.

Nicholson, Helen. The Knights Hospitaller. Woodbridge: Boydell Press, $200 \mathrm{I}$.

Oneto, Gustavo. Mille anni di storia della famiglia Sagramoso. Milano: Pinelli, I 938.

Pagnini, Stefania. "II carteggio Sagramoso alla Biblioteca Capitolare di Verona." Vita Veronese 30 , no. I I - I 2 (I 977): 3 I I -322.

Parry, Clive. The Consolidated treaty series. Vol. 45. Dobbs Ferry: Oceana Publications, 1969.

Pastor, Ludwig von. The History of the Popes. Vol. 39. [Wilmington]: Consortium, I 952.

Pavan-Pagnini, Stefania. "Viaggi in Russia e in Polonia del conte Michele Enrico Sagramoso." Vita Veronese 32 ( 1979): 25-33; 86-92; I 42-1 50; 2 1 3-220.

Pietrzak, Jarosław. "Walka Katarzyny z Sobieskich Radziwiłłowej o dobra ordynacji Ostrogskich w latach 1673-1678. Przyczynek do historii rozpadu latyfundium.” Czasy nowożytne 26 (2013): 53-74.

Riva, Franco. Il carteggio di Michele Enrico Sagramoso. Firenze: Edizioni Sansoni, I 96 I . Rottermund, Andrzej. "Kawalerowie maltańscy w Polsce w XVIII i XIX wieku." In Zakon Maltański w Polsce, edited by Stefan Krzysztof Kuczyński, 85-ı68. Warszawa: Wydawnictwo DiG, 2000.

Stroynowski, Andrzej. “Adam Poniński w obradach delegacji sejmu i 773-1775." Prace Naukowe Akademii im. Jana Dtugosza w Czestochowie. Zeszyty Historyczne I 7 (20 I 8): 59-83.

Stroynowski, Andrzej. “Adam Poniński: marszałek sejmu 1773-1775.” Prace Naukowe Akademii im. Jana Dtugosza w Czestochowie. Zeszyty Historyczne i 5 (20 I 6): I 33 - I 54. Waliszewski, Kazimierz. Potoccy i Czartoryscy. Walka stronnictw i programów politycznych przed upadkiem Rzeczypospolitej I734-I763. Vol I. (I734-I754). Kraków: s.n., I 887. Wheaton, Henry. History of the law of nations in Europe and America. New York: Gould, Banks \& Co., I 845.

Wolska, Barbara. "Wierszowane pamflety polityczne na przywódców sejmu rozbiorowego (1773-1775)." Archiwum Literackie 25 (198 I ): 69- Io6.

Wis, Cristina. "I viaggi nordici di Michele Enrico Sagramoso." Settentrione. Rivista di studi italo-finlandesi I 8 (2006): 365-380.

Zielińska, Teresa. “Ordynacje w dawnej Polsce." Przegląd Historyczny 68, no. I (1977): 17-30.

Zielińska, Teresa. "Poniński Adam.” In Polski Stownik Biograficzny. Vol. 27, edited by Emanuel Rostworowski, 504-5 I I. Wrocław: Zakład Narodowy im. Ossolińskich / Wydawnictwo Polskiej Akademii Nauk, I 983. 